\title{
Helminth communities in three sympatric rodents from the Brazilian Atlantic Forest: contrasting biomass and numerical abundance
}

\author{
Simões, RO. ${ }^{a, b}$, Maldonado-Júnior, A. ${ }^{a}$ and Luque, JL. ${ }^{c *}$ \\ a'Laboratório de Biologia e Parasitologia de Mamíferos Silvestres Reservatórios, \\ Instituto Oswaldo Cruz - FIOCRUZ, Av. Brasil, 4365, Manguinhos, RJ, Brazil

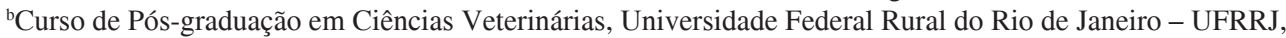 \\ Seropédica, RJ, Brazil \\ 'Departamento de Parasitologia Animal, Universidade Federal Rural do Rio de Janeiro - UFRRJ, \\ CP 74508, CEP 23851-970, Seropédica, RJ, Brazil \\ *e-mail: jlluque@ufrrj.br
}

Received June 30, 2011 - Accepted January 26, 2012 - Distributed November 30, 2012

(With 2 figures)

\begin{abstract}
The study of parasite body size is an important approach to understand the different patterns of helminth community structure, once it is usually analysed using only numerical descriptors which do not capture size heterogeneity among parasite species. In the present study, we compared the pattern in the helminth community of three sympatric wild rodent species Akodon cursor, A. montensis and Oligoryzomys nigripes using numerical abundance and biomass approaches. The cestode Rodentolepis akodontis was the worm with highest biomass in the three rodents. The trichostrongylid Stilestrongylus lanfrediae presented highest biomass in O. nigripes and represented $70 \%$ of the total numeric abundance of parasites. Interestingly, for Akodon spp. the species with more biomass represented less than $10 \%$ of the total numerical abundance. Parasites with the higher numeric abundance do not have the largest body size. Although the biomass pattern is different from numeric abundance, this difference does not influence in the helminth distribution community among the three sympatric hosts. The status change of a helminth species within the community due to its volumetric dominance might justify a new approach since parasites belonging to different taxa obtain resources from the host in different ways.
\end{abstract}

Keywords: biomass, abundance, helminth community structure, sympatric rodents, Atlantic Forest.

\section{Comunidades de helmintos de três roedores simpátricos da Mata Atlântica brasileira: contrastando biomassa e abundância numérica}

\section{Resumo}

A utilização do tamanho do corpo do parasita é uma importante abordagem para compreender diferentes padrões na estrutura da comunidade helmíntica, uma vez que são utilizados apenas descritores numéricos que não necessariamente detectam a heterogeneidade no tamanho entre as espécies de parasitos. No presente estudo, comparou-se o padrão da comunidade helmíntica de três roedores silvestres simpátricos (Akodon cursor, A. montensise e Oligoryzomys nigripes), usando uma abordagem com abundância numérica e biomassa. O cestoide Rodentolepis akodontis foi o helminto com maior biomassa nos três roedores. O tricostrongilídeo Stilestrongylus lanfrediae apresentou uma alta biomassa em $O$. nigripes e representou $70 \%$ da abundância numérica total dos parasitas. Interessantemente, em Akodon spp., a espécie com maior biomassa, representou menos de $10 \%$ da abundância total. Parasitas com maior abundância numérica não foram aqueles com maior tamanho do corpo. Embora o padrão de biomassa determinado tenha sido diferente da abundância numérica, essa diferença não influenciou na distribuição das comunidades de helmintos nos três hospedeiros simpátricos. A mudança do status de uma espécie de helminto dentro da comunidade em função da sua dominância volumétrica pode justificar uma nova abordagem, uma vez que parasitas pertencentes a diferentes táxons podem obter recursos de seu hospedeiro de forma diferente.

Palavras-chave: biomassa, abundância, estrutura da comunidade de helmintos, roedores simpátricos, Mata Atlântica. 


\section{Introduction}

The structure of communities could be determined by the number of species present, their abundances, and realised niches (Lotz, 1985). One of the interespecific patterns most reported is the relationship between abundance and body size (Blackburn et al., 1996). Bini et al. (2001) performed a meta-analytical procedure to combine and compare the slopes of population density and body size relationships across independent studies of mammals and birds and concluded that questions regarding the estimation and validity of slopes is the next challenge of density-body size relationship studies. Patterns in parasite communities are commonly detected using only numerical descriptors, which may not hold when parasite mass is used (Muñoz and George-Nascimento, 2008). Nowadays, studies related to the body size host and their parasite biovolume, mainly in fish, has been increased (Poulin, 1999; Poulin and George-Nascimento, 2007). It is assumed that the total parasite biomass harboured by an individual host species reflects the energy demands of both the host and parasite (George-Nascimento et al., 2002), and can highlight factors that determine the helminth community structure.

Some studies compared infrapopulations and infracommunities using numeric and volumetric data (George-Nascimento et al., 2002; Muñoz and Cribb, 2005; Muñoz and George-Nascimento, 2008). GeorgeNascimento et al. (2004) applied biomass as an indicative of parasite infracommunity productivity. Mouillot et al. (2003) used biomass as a measure of abundance in an investigation of parasite community ecology and the results indicate that interspecific competition does not play a major structure role in parasite community. In mammals, little is known about helminth community structure and biomass. Arnerberg et al. (1998) studied the relationship between body size, life-history traits and population intensity among nematodes and reported that parasite size and intensity were negatively correlated and George-Nascimento et al. (2004) found that in both the numbers and total volume of parasites decreases allometrically with vertebrate host body mass.

The small mammals Akodon montensis Thomas, 1913 and $A$. cursor Winge, 1887 are cursorial rodents and have diurnal behaviour (Emmons and Feer, 1997) while Oligoryzomys nigripes Olfers, 1818 is a scansorial rodent with nocturnal behaviour. The three species living in sympatric conditions in the Atlantic Forest (Gentile and Fernandez, 1999), and share soil resources. Simões et al. (2011) observed using numeric descriptors that sympatric rodents phylogenetically related have a different community structure although it presented a similar component community.

Here we compared the numerical and volumetric descriptors of parasite population (abundance) in the helminth communities of three wild rodents: Akodon cursor, A. montensis and $O$. nigripes.

\section{Material and Methods}

One hundred and twenty-eight specimens of Akodon montensis, 23 A. cursor and 53 Oligoryzomys nigripes were collected in the locality of Teresópolis $\left(22^{\circ} 24^{\prime} 36^{\prime}\right.$ ' $\mathrm{S}$, $\left.42^{\circ} 58^{\prime} 48^{\prime \prime} \mathrm{W}\right)$, Atlantic Forest, Rio de Janeiro, Brazil, over two years (2004-2005) with live traps Tomahawk ${ }^{\circledR}$ and Sherman ${ }^{\circledR}$. All animal procedures followed the guidelines for capture, handling and care of mammals of the American Society of Mammalogy and the biosecurity procedures of the Brazilian Health Ministry. The animals were collected under the permission of the Brazilian government's Institute for Wildlife and Natural Resources (IBAMA numbers 012/2004 and 068/2005). Bio-security techniques and individual safety equipment were used during all procedures involving animals or biological samples (Lemos and D'Andrea, 2006). After being euthanised under biological safety procedures, the helminths were collected and identified as described by Simões et al. (2011).

All helminths were quantified for each taxon in each individual rodent. Ten specimens of each taxon were measured for length and width to estimate its body size. The body mass of each helminth species was expressed as the volume $\left(\mathrm{mm}^{3}\right)$ of a cylinder (nematodes) and an ellipsoid (trematode and cestode) according to GeorgeNascimento et al. (2004).

In addition, numerical abundance (Bush et al., 1997) was calculated as total number of each helminth species per host specimen collected. The biomass was calculated as abundance multiplied by the mean of parasite body volume of a helminth (George-Nascimento et al., 2002). Chi-squared analyses were used to test significant differences in the relative abundance and biomass of parasites among the three species of rodents. Pearson correlations were applied to relate the numeric abundance and biomass in helminth infracommunities. All data were previously logarithmized $\log (\mathrm{x}+1)$ (Zar, 1999). The level of statistical significance was taken to be $\mathrm{P}<0.05$. Analysis of variance (ANOVA) on $\log (\mathrm{x}+1)$ transformed data was used for comparison of biomass helminths common among the three rodents, and statistical significance was tested by comparing the F-test statistic (Zar, 1999). The relative species abundance and biomass in the helminth component communities of the three sympatric rodents were also calculated in order to compare.

Canonical multivariate analysis (CMA) was performed using helminth biomass as explanatory variables previous $\log (\mathrm{x}+1)$ transformation of biomass data for each helminth species. This analysis was performed following the recommendations of Wilkinson (1990) using the SYSTAT ${ }^{\circledR}$ statistical software.

\section{Results}

In the three hosts studied, the body volume of individual parasites varied from $0.004 \mathrm{~mm}^{3}$ in the nematode Stilestrongylus eta to $320.54 \mathrm{~mm}^{3}$ in the cestode Rodentolepis akodontis (Table 1). In Akodon cursor the cestode 
R. akodontis, and the nematodes Angiostrongylus lenzi, Litomosoides silvai and Syphacia carlitosi are the species with higher biovolume, while in A. montensis are R. akodontis, L. silvai, Protospirura numidica and the trematode Canaania obesa, respectively. In $O$. nigripes, the cestode $R$. akodontis and the nematodes Stilestrongylus lanfrediae, Guerrerostrongylus zetta and S. kinselai presented the highest biovolume in the component community.

Comparing the numeric abundance and biovolume, $R$. akodontis had the highest biomass in the three rodent species, in spite of the relative low abundance. The trichostrongylid $S$. lanfrediae presented high biomass in $O$. nigripes when compared to the other species, however, this species represented $70 \%$ of the total numeric abundance of parasites (Table 2). Interestingly, for Akodon spp. the species with more biomass represented less than $10 \%$ of the total numeric abundance.

Considering the trichostrongylids parasitising the three species of rodents, the two more prevalent species are: S. aculeata and S. eta in Akodon spp. and S. lanfrediae and
G. zetta in O. nigripes. Together these species represent more than $50 \%$ of the total helminth abundance, however; these worms do not express more than $1 \%$ of the biovolume total.

The comparison between relative numeric abundance and biomass in the three rodents revealed significant differences for the following species: $R$. akodontis, $S$. lanfrediae and S. eta in Akodon spp. and O. nigripes; S. aculeata in A. cursor; G. zetta in A. cursor and O. nigripes; Avellaria sp. in A. montesis and O. nigripes; S. carlitosi and Angiostrongylus lenzi in A. montensis and S. kinsellai in O. nigripes (Table 3 ).

The biomass comparison of common species to A. cursor, A. montensis and $O$. nigripes revealed significant differences for $C$. obesa $(\mathrm{F}=3.12 ; \mathrm{P}<0.05)$, R. akodontis $(\mathrm{F}=3.20, \mathrm{P}<0.05)$, S. lanfrediae $(\mathrm{F}=37.61, \mathrm{P}<0.01)$, S. aculeata $(\mathrm{F}=8.58, \mathrm{P}<0.01)$ except for $S$. eta. Only $O$. nigripes showed positive correlation between parasite biomass and numerical abundance $(\mathrm{r}=0.77, \mathrm{P}<0.05$, $\mathrm{n}=9$ ) (Figures 1a-c).

Table 1. Mean body volume in $\mathrm{mm}^{3}$ (MBV), prevalence (\%), numerical abundance (Num.) and biomass (Bio.) of helminth species parasitic in Akodon cursor, A. montensis and Oligoryzomys nigripes from Brazilian Atlantic Forest.

\begin{tabular}{|c|c|c|c|c|c|c|c|c|c|c|}
\hline & \multirow{2}{*}{ MBV } & \multicolumn{3}{|c|}{ Akodon cursor } & \multicolumn{3}{|c|}{ Akodon montensis } & \multicolumn{3}{|c|}{ Oligoryzomys nigripes } \\
\hline & & $\%$ & Num. & Bio. & $\%$ & Num. & Bio. & $\%$ & Num. & Bio. \\
\hline \multicolumn{11}{|l|}{ TREMATODA } \\
\hline Canaania obesa & 0.95 & 12.5 & 0.36 & 0.15 & 16.9 & 1.18 & 1.56 & 3.7 & 0.17 & 0.17 \\
\hline \multicolumn{11}{|l|}{ CESTODA } \\
\hline Rodentolepis akodontis & 320.54 & 16.7 & 0.64 & 179.51 & 24.3 & 0.29 & 85.91 & 3.7 & 0.04 & 17.17 \\
\hline \multicolumn{11}{|l|}{ NEMATODA } \\
\hline Stilestongylus lanfrediae & 0.04 & 4.2 & 7.1 & 0.23 & 6.6 & 1 & 0.04 & 88.9 & 26.5 & 1.21 \\
\hline Stilestrongylus aculeata & 0.01 & 25 & 3.55 & 0.05 & 46.3 & 10.4 & 0.15 & 14.8 & 0.55 & 0.008 \\
\hline Stilestrongylus eta & 0.004 & 33 & 5.86 & 0.02 & 44.9 & 5.6 & 0.03 & 5.6 & 0.98 & 0.004 \\
\hline Guerrerostrongylus zetta & 0.16 & 4.2 & 0.05 & 0.002 & - & - & - & 18.5 & 5.14 & 1.14 \\
\hline Trichofreitasia lenti & 0.03 & - & - & - & 8.1 & 0.37 & 0.13 & 5.6 & 0.09 & 0.01 \\
\hline Angiostrongylus lenzi & 1.25 & 4.2 & 0.41 & 0.64 & 1.5 & 0.01 & 0.003 & - & - & - \\
\hline Avellaria sp. & 0.02 & - & - & - & 0.7 & 0.06 & 0.001 & 1.9 & 0.31 & 0.002 \\
\hline Protospirura numidica & 9.06 & - & - & - & 2.2 & 0.06 & 0.56 & - & - & - \\
\hline Syphacia carlitosi & 0.11 & 12.5 & 0.23 & 0.15 & 6.6 & 0.68 & 0.12 & - & - & - \\
\hline Syphacia kinsellai & 0.09 & - & - & - & - & - & - & 24.1 & 4.07 & 0.69 \\
\hline Litomosoides silvai & 1.44 & 12.5 & 0.09 & 0.53 & 2.2 & 0.41 & 0.90 & - & - & - \\
\hline
\end{tabular}

Table 2. Relative abundance and relative biomass of the helminth component communities of three sympatric rodent species from Brazilian Atlantic Forest.

\begin{tabular}{lcccccc}
\hline \multirow{2}{*}{ HELMINTH SPECIES S } & \multicolumn{2}{c}{ Akodon cursor } & \multicolumn{2}{c}{ Akodon montensis } & \multicolumn{2}{c}{ Oligoryzomys nigripes } \\
\cline { 2 - 7 } & Abundance & Biomass & Abundance & Biomass & Abundance & Biomass \\
\hline Stilestrongylus lanfrediae & 0.38 & $<0.001$ & 0.05 & $<0.001$ & 0.70 & 0.056 \\
Stilestrongylus aculeata & 0.19 & $<0.001$ & 0.52 & 0.002 & 0.01 & $<0.001$ \\
Stilestrongylus eta & 0.32 & $<0.001$ & 0.28 & $<0.001$ & 0.03 & $<0.001$ \\
Rodentolepis akodontis & 0.04 & 0.990 & 0.01 & 0.960 & $<0.01$ & 0.840 \\
All other species & 0.06 & 0.008 & 0.15 & 0.034 & 0.23 & 0.100 \\
\hline
\end{tabular}


The classification matrix based on biomass data indicates that overall, $76 \%$ of helminths were correctly classified within a helminth community. Figure 2 indicates that the helminth community is differently structured in $O$. nigripes (Wilks's lambda 0.501; d.f. 13, 177; approximately $\mathrm{F}=5.242 ; \mathrm{P}<0.001)$.

\section{Discussion}

The number of individual parasites per host described by Bush et al. (1997) is defined as parasite abundance and has a substantial importance to evaluate the parasitism as an ecological process or a selective force (Poulin and GeorgeNascimento, 2007). Usually parasite communities and infracommunities are described only numerically, specially in rodents (Fuentes et al., 2004; Maldonado Junior et al., 2006; Simões et al., 2009, 2011). Nevertheless, the size of the parasites is relevant information in order to understand how much parasite biomass can be sustained and how it can determine the helminth community structure. Moreover, parasite biomass could be a more relevant measure of parasite abundance than the total number of parasite individuals, because the parasite body size can be used as a proxy for productivity (Mouillot et al., 2003) and estimates of parasite energetic requirements (GeorgeNascimento et al., 2004). In the present study the species with more biomass (biovolume) represented less than $10 \%$ of total numeric abundance, reinforcing the importance of include the parasite biovolume in the analysis of the structure of helminth communities. As noted by GeorgeNascimento et al. (2002), in fishes, low abundant but large biovolumetric species could generate a different infracommunity pattern than those based on numerical data alone. Our results are similar to those observed in fishes: when an individual host harbours a high parasite biomass, one or a few dominant parasite species account for most of the biovolume (Mouillot et al., 2003). Muñoz and Cribb (2005) showed that different parasite species can differ widely in size, such that two species with equal numerical abundance can show variability (one or more times) in their biomass, as observed for A. lenzi and $R$. akodontis in A. cursor.

Significant correlation between parasitological parameters and parasite body volume was not observed in fish (George-Nascimento et al., 2002; Muñoz and Cribb, 2005). However, for mammals, Arneberg et al. (1998) observed that parasite body size was correlated to intensity. Wentes corroborates this finding, since a similar pattern was observed between abundance and biomass in $O$. nigripes, but not in Akodon spp. This pattern may be determined by the three most abundant helminth species in $O$. nigripes which present a high biomass, although the same was not seen in Akodon spp.. Thus, sympatric hosts with different behaviour present different helminth community structure (Simões et al., 2011) and different parasite body size. Studies on ecology of the host-parasitehabitat are necessary considering the biomass pattern in parasite communities (Poulin, 2007).

Interestingly, although the biomass pattern is different from numeric abundance, this difference does not influence the helminth distribution community, since the canonical multivariate analysis using biomass data was similar to that observed in Simões et al. (2011) using numeric abundance in the three sympatric rodents.

Finally, it is clear that parasites with the highest abundance are not the largest and some species are numerically important, while others are volumetrically important (biomass), which may be connected to parasite-host specificity, resources and niche necessary for each helminth species. So when we sudy the helminth community structure, body parasite size can be an important description, since change of the status of a particular parasite species within the community due to its volumetric dominance justifies

Table 3. Chi-squared $\left(\mathrm{X}^{2}\right)$ values for comparisons of relative abundance and biomass of the helminth parasite species in three sympatric rodent species from the Brazilian Atlantic Forest, Brazil.

\begin{tabular}{lcccccc}
\hline \multirow{2}{*}{ Helminth species } & \multicolumn{2}{c}{ Akodon cursor } & \multicolumn{2}{c}{ Akodon montensis } & \multicolumn{2}{c}{ Oligoryzomys nigripes } \\
\cline { 2 - 7 } & $\mathbf{X}^{\mathbf{2}}$ & $P$ & $\mathbf{X}^{\mathbf{2}}$ & $P$ & $\mathbf{X}^{\mathbf{2}}$ & $P$ \\
\hline Canaania obesa & 100.90 & $<0.01$ & 20.14 & $<0.01$ & 0.20 & $>0.05$ \\
Rodentolepis akodontis & 81.04 & $<0.01$ & 681.30 & $<0.01$ & 38.03 & $<0.01$ \\
Stilestongylus lanfrediae & 6.96 & $<0.01$ & 38.03 & $<0.01$ & 84.23 & $<0.01$ \\
Stilestrongylus aculeata & 44.12 & $<0.01$ & 0.002 & $>0.05$ & 11.93 & $<0.01$ \\
Stilestrongylus eta & 16.32 & $<0.01$ & 30.27 & $<0.01$ & 0.45 & $>0.05$ \\
Guerrerostrongylus zeta & 109.43 & $<0.01$ & - & - & 72.99 & $<0.01$ \\
Trichofreitasia lenti & 2.80 & $>0.05$ & 2.01 & $>0.05$ & 0.02 & $>0.05$ \\
Angiostrongylus lenzi & - & - & 109.10 & $<0.01$ & - & - \\
Avellaria sp. & - & - & 109.45 & $<0.01$ & 110.32 & $<0.01$ \\
Protospirura numidica & - & - & 0.21 & $>0.05$ & - & - \\
Syphacia carlitosi & 1.33 & $>0.05$ & 11.41 & $<0.01$ & - & - \\
Syphacia kinsellai & - & - & - & - & 70.99 & $<0.01$ \\
Litomosoides silvai & 0.09 & $>0.05$ & 0.33 & $>0.05$ & - & - \\
\hline
\end{tabular}



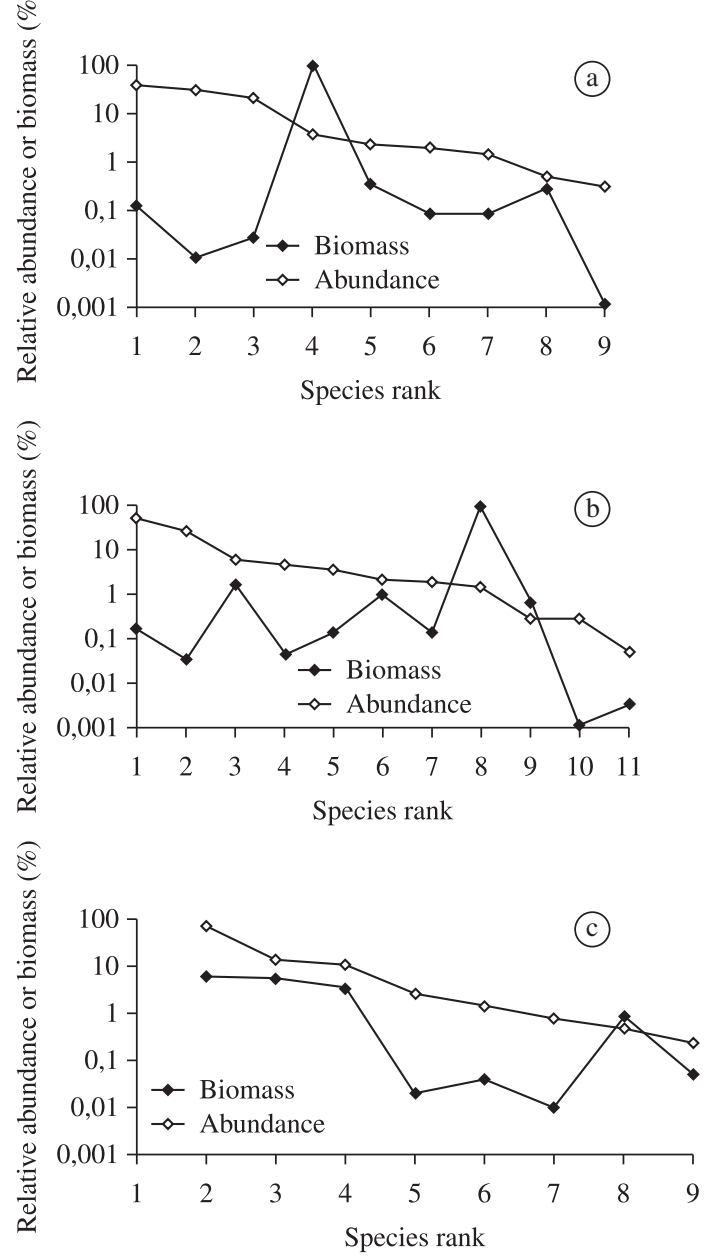

Figure 1. Relative species abundance and biomass in helminth community of Akodon cursor (a), A. montensis (b), Oligoryzomys nigripes (c). Helminth species are ranked from most to least abundant.

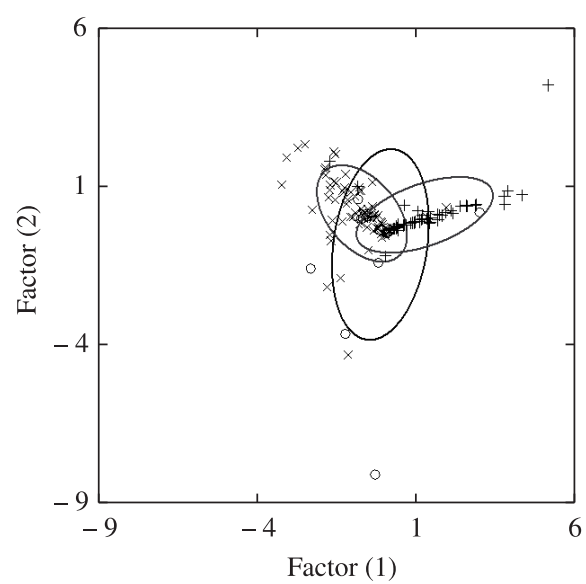

Figure 2. Results of canonical multivariate analysis showing host discrimination using biomass data for each helminth species; Akodon cursor (O), Akodon montensis (X) and Oligoryzomys nigripes (+). new approaches because those belonging to different taxa obtain resources from the host in different ways.

Acknowledgements - We would like to thank Paulo S. D'Andrea for help in rodent capture and PAPES IV (Strategic Program to Support Health Research) for funding. R.O.S. was supported by a graduate fellowship from CAPES (Coordenação de Aperfeiçoamento de Pessoal de Nível Superior). J.L.L. was supported by a fellowship from CNPq (Conselho Nacional de Desenvolvimento Científico e Tecnológico, Brazil).

\section{References}

ARNEBERG, P., SKORPING, A. and READ, AF., 1998. Parasite abundance, body size, life histories, and the energetic equivalence rule. The American Naturalist, vol. 151, no. 6, p. 50-56. PMid:18811372. http://dx.doi.org/10.1086/286136

BLACKBURN, TM., LAWTON, JH. and GREGORY, RD., 1996. Relationships between abundances and life histories of British birds. Journal of Animal Ecology, vol. 65, no. 1, p. 52-62. http:// dx.doi.org/10.2307/5699

BINI, LM., COELHO, ASG. and DINIZ-FILHO, JAF., 2001. Is the relationship between population density and body size consistent across independent studies? a meta-analytical approach. Brazilian Journal of Biology, vol. 61 no. 1, p. 1-6. http://dx.doi. org/10.1590/S0034-71082001000100002

BUSH, AO., LAFFERTY, KD., LOTZ, JM. and SHOSTAK, AW., 1997. Parasitology meets ecology in its own terms: Margolis et al. revisited. Journal of Parasitology, vol. 86, no. 4, p. 575-583.

EMMONS, LH. and FEER, F., 1997. Neotropical rainforest mammals. A field guide. 2nd ed. Chicago and London: University of Chicago Press. 307 p.

FUENTES, MV., SÁEZ, S., TRELIS, V., GALÁN-PUNCHADES, MT. and ESTEBAN, JG., 2004. The helminth community of the wood mouse, Apodemus sylvaticus, in the Sierra Espuña, Murcia, Spain. Journal of Helminthology, vol. 78, no. 3, p. 219-223. PMid:15469624.

GENTILE, R. and FERNANDEZ, FAS., 1999. Influence of habitat structure on a strem side small mammal community in a Brazilian rural area. Mammalia, vol. 63, no. 1, p. 29-40. http:// dx.doi.org/10.1515/mamm.1999.63.1.29

GEORGE-NASCIMENTO, M., GARCÍAS, F., and MUÑOZ, G., 2002. Parasite body volume and infracommunity patterns in the southern pomfret Brama australis (Pisces: Bramidae). Revista Chilena de Historia Natural, vol. 75, no. 4, p. 835-839. http:// dx.doi.org/10.4067/S0716-078X2002000400016

GEORGE-NASCIMENTO, M., MUNÕZ, G., MARQUET, PA. and POULIN, R., 2004. Testing the energetic equivalence rule with helminth endoparasites of vertebrates. Ecology Letters, vol. 7, no. 7, p. 527-531. http://dx.doi.org/10.1111/j.1461-0248.2004.00609.x

LEMOS, ERS. and D'ANDREA, PS., 2006. Trabalho com animais silvestres. In MARTINS, EV., MARTINS, AS., SILVA, FHAL., LOPES, MCM., MORENO, MLV. and SILVA, PCT. Biossegurança, informação e conceitos, textos básicos. Rio de Janeiro: FIOCRUZ. p. 273-288.

LOTZ, JM. and FONT, WF., 1985. Structure of enteric communities in two populations of Eptesicus fuscus (Chiroptera). Canadian Journal of Zoology, vol. 63, no. 12, p. 2969-2978. http://dx.doi. org/10.1139/z85-445 
MALDONADO JUNIOR, A., GENTILE, R., FERNANDESMORAES, CC., D'ANDREA, PS., LANFREDI, RM. and REY, L., 2006. Helminth communities of Nectomys squamipes naturally infected by the exotic trematode Schistosoma mansoni in southeastern Brazil. Journal of Helminthology, vol. 80, no. 4, p. 369-375. PMid:17125546. http://dx.doi.org/10.1017/JOH2006366

MOUILLOT, D., GEORGE-NASCIMENTO, M. and POULIN, R. 2003. How parasites divide resources: a test of the niche apportionment hypothesis. Journal of Animal Ecology, v. 72, no. 7, p. 757-764, 2003. http://dx.doi.org/10.1046/j.13652656.2003.00749.x

MUÑOZ, SA. and GEORGE-NASCIMENTO, M., 2008. The effects of Anonchocephalus chilensis Riggenbach (Eucestoda: Bothriocephalidea) on infracommunity patterns in Genypterus maculatus Tschudi (Osteichthyes: Ophidiidae). Journal of Helminthology, vol. 82, no. 3, p. 221-226. PMid:18394212.

MUÑOZ, G. and CRIBB, TH., 2005. Infracommunity structure of parasites of Hemigymnus melapterus (Pisces: Labridae) from lizard island, Australia: The importance of habitat and body size. Journal of Parasitology, vol. 91, no. 1, p. 38-44. PMid:15856869. http://dx.doi.org/10.1645/GE-3321

POULIN, R., 1999. Body size vs abundance among parasite species: positive relationships? Ecography, vol. 22, no. 3, 246-250. http:// dx.doi.org/10.1111/j.1600-0587.1999.tb00499.x
POULIN, R., 2007. Evolutionary Ecology of Parasites. 2nd ed. Princeton: Princeton University Press. 332 p.

POULIN, R. and GEORGE-NASCIMENTO, M., 2007. The scaling of total parasite biomass with host body mass. International Journal for Parasitology, vol. 37, no. 3-4, p. 359-364. PMid:17196596. http://dx.doi.org/10.1016/j.ijpara.2006.11.009

SIMÕES, RO., SOUZA, JGR., MALDONADO JUNIOR, A. and LUQUE, JL., 2011. Variation in the helminth community structure of three sympatric sigmodontine rodents from the coastal Atlantic Forest of Rio de Janeiro, Brazil. Journal of Helminthology, vol. 85, no. 2, p. 171-178. PMid:20701831. http://dx.doi.org/10.1017/ S0022149X10000398

SIMÕES, RO., GENTILE, R., RADEMAKER, V., D'ANDREA, PS., HERRERA, H., FREITAS, T., LANFREDI, R. and MALDONADO JUNIOR, A., 2009. Variation in the helminth community structure of Thrichomys pachyurus (Rodentia: Echimyidae) in two subregions of the Brazilian Pantanal: the effects of land use and seasonality. Journal of Helminthology, vol. 84, no. 3, p. 266-275. PMid:19849884.

WILKINSON, L., 1990. SYSTAT: The system for statistics. Evanston: Systat Inc. 822 p.

ZAR, JH., 1999. Biostatistical Analysis. 4th ed. New Jersey: Prentice Hall. 960 p. 